\title{
SOME OBSERVATIONS ON SUBGLACIAL GROUND-WATER FLOW
}

\author{
By C. C. SMART
}

(Department of Geography, University of Western Ontario, London, Ontario N6A 5C2, Canada)

\begin{abstract}
Conduit and regelation water are inferred to drain as ground water from up to $130 \mathrm{~km}^{2}$ of Columbia Icefield. Subglacial conduits appear to be generally occupied by free surface streams. Ground-water flow will allow exchange between the regelation film and conduits. Present-day discharge from beneath the accumulation zone carries little sediment, and past injections of sediment appear to correspond to ancient interglacials. Transport of sediment through cave passages may be analogous to transport through basal conduits.
\end{abstract}

RÉSUMÉ. Quelques observations sur l'écoulement des nappes aquiféres sous glaciaires. On suppose que, sur près de $130 \mathrm{~km}^{2}$, l'eau des cheneaux et l'eau de fonte-regel est drainée sous forme de nappe aquifére dans le Columbia Icefield. Les cheneaux sous glaciaires semblent généralement empruntés par des écoulements libres. L'écoulement de la nappe aquifére permet des échanges entre l'eau du film de fonte-regel et celle des cheneaux. Actuellement les

\section{INTRODUCTION}

Subglacial ground-water flow in karst terrain has been recognized for many years, but information on the processes of drainage at the glacier bed has remained scarce. A large part of Columbia Icefield, Alberta, Canada, appears to be drained through a karst aquifer and Castleguard Cave has allowed access to the glacier bed so that these processes may be studied. The hydrology of this area was described by Smart (1983). Up to $130 \mathrm{~km}^{2}$ of glacier bed was shown to be freely drained by karst. In particular, ground-water flow was found at two scales: in large discrete conduits, and as smaller diffuse drips and seeps commonly associated with stalactites. An association between the basal regelation film and the diffuse seepage, and between conduit flow in both the glacier and ground water was suggested. The morphology of recently abandoned pro-glacial surfaces supported this association. A dye test from a moulin on Saskatchewan Glacier demonstrated rapid flow of englacial water to springs over $8 \mathrm{~km}$ away in Castleguard Valley.

Continuing work on the subject has prompted this short note which provides further information on the hydrology of the glacier bed and some related observations on subglacial sediment generation.

\section{FURTHER OBSERVATIONS}

Aerial photographs and a recent map of Columbia Icefield (National Hydrological Research Institute, 1980) show a pond in a closed depression on the glacier surface. Muir and Ford (1985) illustrated this depression and observed that it is $200 \mathrm{~m} \times 50 \mathrm{~m}$ in plan and perhaps $20-30 \mathrm{~m}$ deep. There is some evidence of fluctuating water level in the pond, and the icefield is drained centripetally to this point. The depression lies somewhat to the east of an inferred bedrock depression beneath the icefield (Smart, 1983, fig. 6, p. 478) but closely overlies a part of Castleguard Cave exhibiting abundant ground-water flow.

Below the icefield in Castleguard Cave there is usually

a wind blowing. This is a chimney-effect wind (Atkinson écoulements provenant de la zone d'accumulation sont peu chargés en sédiments et les anciens apports de sédiments semblent s'être produit lors d'anciens stades interglaciaires. Le transport de sédiments dans les cavités karstiques peut être comparable à celui qui se produit dans les cheneaux sous glaciaires.

ZUSAMMENFASSUNG. Einige Beobachtungen zum Fluss subglazialen Grundwassers. Führungs- und Regelationswasse ist als Grundwasser am Abfluss von bis $\mathrm{zu} 130 \mathrm{~km}^{2}$ des Columbia Icefield beteiligt. Subglaziale Wasserführungen scheinen im allgemeinen durch freie Oberflächenströme benutzt zu werden. Der Grundwasserfluss gestattet den Austausch zwischen dem Regelationsfilm und den Führungen. Der derzeitige Abfluss unter der Akkumulationszone enthält wenig Sediment; frühe Zugaben von Sediment scheinen alten Interglazialstadien zu entsprechen. Der Sedimenttransport durch höhlenartige Passagen dürfte analog zum Transport durch Kanäle am Untergrund ablaufen.

and others, 1983) driven by temperature differences between the cave and the surface. In winter, the wind blows up through the cave and is presumably vented to the surface through solutional shafts in bedrock overlain by about $300 \mathrm{~m}$ of glacier ice. There are numerous crevasses in the icefield surface above this point which presumably carry the wind. Attempts to demonstrate air discharge at the surface have so far been frustrated. In summer, the shafts carry both melt water and air down into the cave. Some shafts carry neither water nor air, and are plugged by clean polycrystalline glacier ice. Not only is the intruded ice clean, but ground water draining from the icefield also carries little sediment. In contrast, most of the $18 \mathrm{~km}$ of the cave has been occupied by silt-clay laminates presumably of glacial origin. It was originally hypothesized that these were deposited during three glacial epochs (Schroeder and Ford, 1983). However, further study of these sediments shows no uniform stratigraphy. Some sections exhibit sequences of erosion-scoured surfaces followed by coarse intraclasts and then a progressive fining upwards. These are micro-turbidites. Other sites show more or less uninterrupted deposition. Sediment appears to have frustrated solutional development of much of the upper reaches of the cave, resulting in a complex series of passages which have been variously formed, infilled and flushed. Anastomosing networks of small tubes have developed in the walls and roof of infilled passages. In places, the sediments are interlain with calcite speleothem possessing a reversed magnetic polarity, suggesting an age of at least $700 \mathrm{ka}$ (Gascoyne and others, 1983). Furthermore, samples of the sediment contain pollen from broad-leafed species not reported from the Holocene record of the area (Gale and others, 1985).

Atandoned glacier beds may retain evidence of former basal drainage systems (Walder and Hallet, 1979), and segmenis of former channel networks cut into limestone are found throughout the Rocky Mountains. These channels frequently contain abandoned waterfalls (Fig. la) and incised meanders (Fig. $1 \mathrm{~b}$ ). In areas where former glacier-bed slopes
are oblique to the previous ice surface, most channel 

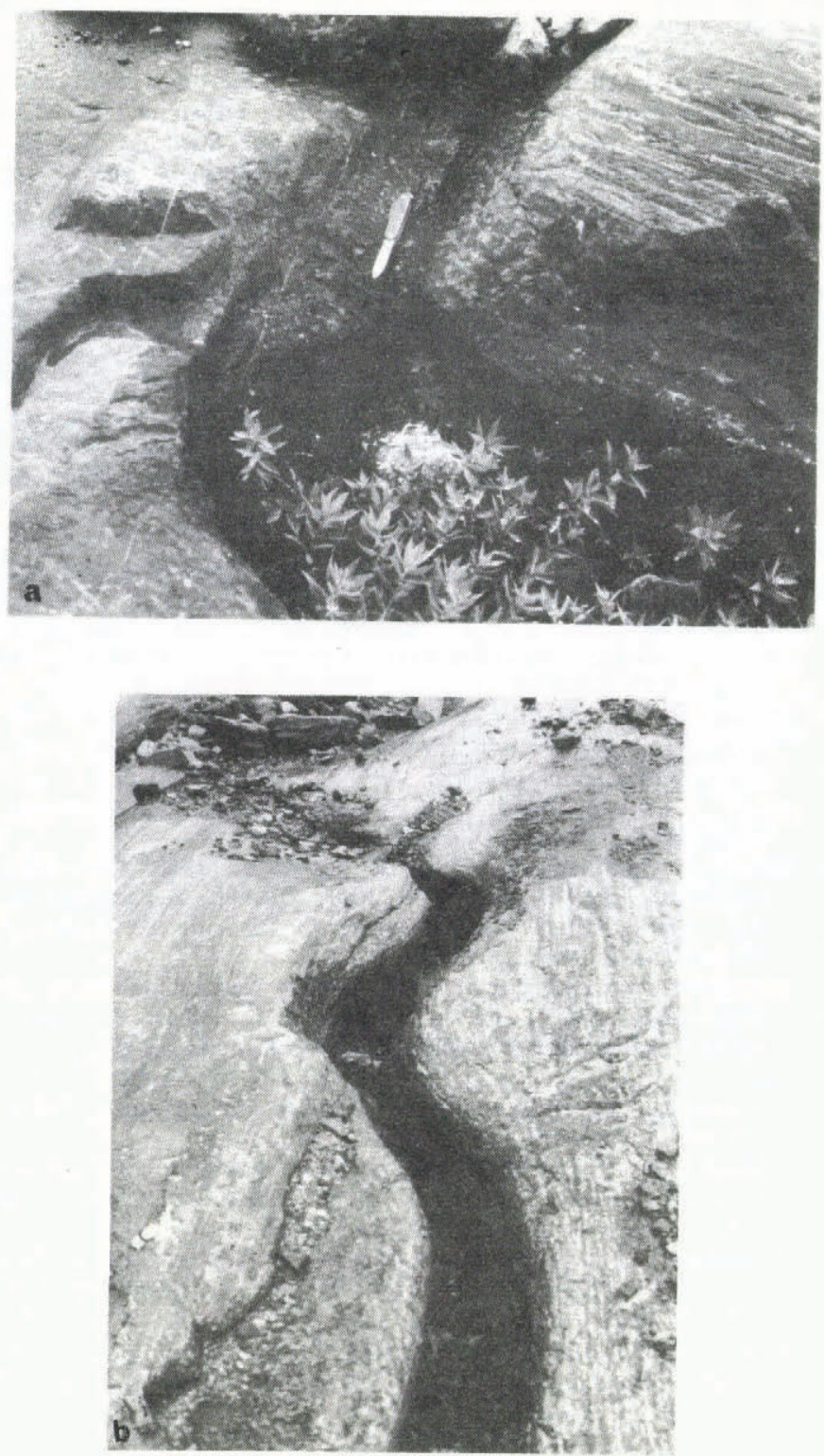

Fig. 1. Short Nye-channel segments showing: (a) a retreating waterfall; (b) meander migration with incision. Both these features are about $30 \mathrm{~cm}$ in width, and both terminate at the head of karst shafts. A zone free of precipitates and striations is seen in the top right-hand corner of (b).

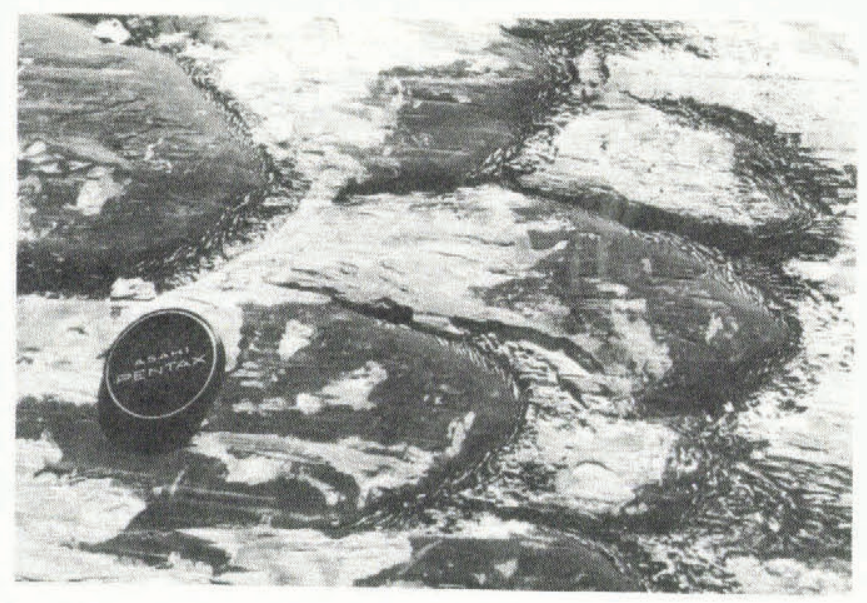

Fig. 2. Zones of calcite solution and precipitation on a recently exposed glacier bed represent the action of $a$ regelation water film. The lens cap is $50 \mathrm{~mm}$ in diameter.
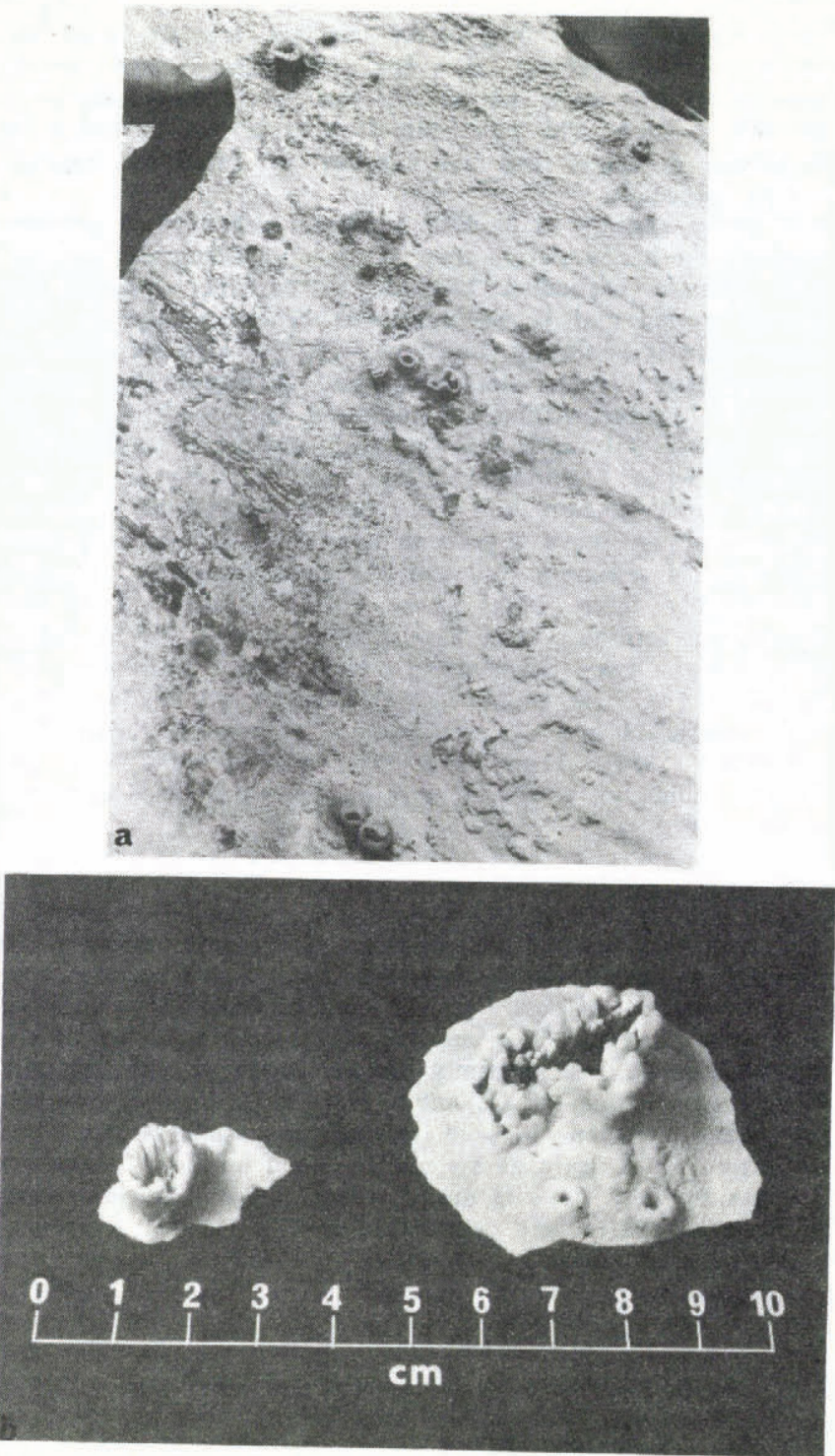

Fig. 3. Subglacial "stalactites" show calcite precipitation to have occurred at the outlet of small fractures in lee cavities. The regelation film is inferred to have leaked through bedrock.

remnants are oriented down-dip rather than directly towards the former ice margin (e.g. Smart, 1983, fig. 2, p. 573). Abundant calcite precipitates co-exist with these channel remnants (Fig. 2), although in places striation and precipitate-free patches are found (Fig. 1b). Fine fractures in the lee side of bedrock steps are of ten marked by annular calcite "crowns" (Fig. 3a and b). These are assumed to mark the outlets of small-scale seeps through bedrock (Smart, 1983).

\section{DISCUSSION}

The waterfalls, incised meanders, and down-dip channels are all characteristic of open-channel rather than closed-conduit flow. These observations plus the perennial cave wind therefore confirm Lliboutry's (1983) assertion that water in subglacial conduits is generally under low or atmospheric pressure.

Furthermore, they persist through winter. The channel remnants are by definition "Nye-channels". They must have been linked by "Röthlisberger-channels" which have left no evidence of their presence, but must have re-formed annually in order to create the Nye-channels. All the channels observed are far larger than those considered by Weertman and Birchfield (1983). Exchange of water between the conduit and regelation system is not normally possible (Weertman, 1972), but a permeable glacier bed will permit 
exchange of water. Despite the massive pressure gradient, however, the bulk of the regelation film is not totally drained. If this were the case, calcite precipitates would not be able to form. The precipitate-free areas may be zones of preferred drainage, but the absence of striations suggests cavity formation.

There appears to be little sediment generated at present beneath the accumulation zone of part of Columbia Icefield. The massive carbonate bedrock is certainly resistant to glacial erosion and forms prominent benches. However, this observation is generally consistent with the high elevation of cirques despite their more prolonged occupation by glacier ice. The massive influxes of sediment into the cave in the past appear to mark ancient and profound interglacials, possibly when Columbia Icefield was reduced to a few minor cirque glaciers and the sink points became distal or pro-glacial. The cave appears to have been unable to convey the imposed sediment load and has been repeatedly plugged. Occasionally these plugs have burst, causing scour and subsequent settling which have generated the local turbidite sequences. Cave development has been redirected by sediment fill. The anastomosing passages are hydraulically very inefficient and are well knawn from karst studies (e.g. Lauritzen, 1981). There is a clear analogy here with the events leading up to glacier surging described by Kamb and others (1985).

\section{CONCLUSIONS}

Subglacial ground-water flow can be significant in alpine karst areas, but it is unclear whether this is also true for ordinary diffuse ground-water flow. In general, subglacial conduit flow appears to be in open channels. Little sediment is presently being produced beneath the accumulation zone of Columbia Icefield, although abundant material has been injected during past interglacials. The subglacial karst drainage system has been unable to transport all the injected material during these periods. Further work is presently under way on these sites.

\section{REFERENCES}

Atkinson, T.C., and others. 1983. Climate and natural radon levels in Castleguard Cave, Columbia Icefields, Alberta, Canada, by T.C. Atkinson, P.L. Smart, and T.M.L. Wigley. Arctic and Alpine Research, Vol. 15, No. 4, p. 487-502.
Gale, S.J., and others, 1985. The Castleguard Formation, its age and its implications for Cenozoic landscape development in the Canadian Rockies. (Abstract.) By S.J. Gale, C.O. Hunt, and C.C. Smart. (In Spencer, T., ed. International geomorphology 1985. Abstracts of papers for the First International Conference on Geomorphology, p. 204.)

Gascoyne, M., and others. 1983. The antiquity of Castleguard Cave, Columbia Icefields, Alberta, Canada, by M. Gascoyne, A.G. Latham, R.S. Harmon, and D.C. Ford. Arctic and Alpine Research, Vol. 15, No. 4, p. 463-70.

Kamb, B., and others. 1985. Glacier surge mechanism: 1982-1983 surge of Variegated Glacier, Alaska, by B. Kamb [and 7 others]. Science, Vol. 227, No. 4686, p. 469-79.

Lauritzen, S.-E. 1981. Simulation of rock pendants - small scale experiments. (In Beck, B.F., ed. Proceedings of the Eighth International Congress of Speleology ... Bowling Green, Kentucky, U.S.A., July 18 to 24, 1981. Americus, GA, Georgia Southwestern College. Department of Geology, p. 407-09.)

Lliboutry, L. 1983. Modifications to the theory of intraglacial waterways for the case of subglacial ones. Journal of Glaciology, Vol. 29, No. 102, p. 216-26.

Muir, D., and Ford, D.C. 1985. Castleguard. Ottawa, Supplies and Services Canada.

National Hydrological Research Institute. 1980. Columbia Icefields, 1:50 000 map sheet 1011. Ottawa, Department of the Environment. Inland Waters Directorate. National Hydrological Research Institute.

Schroeder, J., and Ford, D.C. 1983. Clastic sediments in Castleguard Cave, Columbia Icefields, Alberta, Canada. Arctic and Alpine Research, Vol. 15, No. 4, p. 451-61.

Smart, C.C. 1983. The hydrology of the Castleguard karst, Columbia Icefields, Alberta, Canada. Arctic and Alpine Research, Vol. 15, No. 4, p. 471-86.

Walder, J., and Hallet, B. 1979. Geometry of former subglacial water channels and cavities. Journal of Glaciology, Vol. 23, No. 89, p. 335-46.

Weertman, J. 1972. General theory of water flow at the base of a glacier or ice sheet. Reviews of Geophysics and Space Physics, Vol. 10, No. 1, p. 287-333.

Weertman, J., and Birchfield, G.E. 1983. Stability of sheet water flow under a glacier. Journal of Glaciology,Vol. 29, No. 103 , p. 374-82. 